\title{
Construction of an Individual Educational Trajectory as a Way to Reveal the Personal and Professional Potential of a Future Teacher
}

\author{
Anna I. Klieba ${ }^{1}$, Yuliia O. Bludova², Nataliia A. Galushko ${ }^{3}$, Olena H. Pavlova ${ }^{4} \&$ Nataliia V. Pylypenko ${ }^{2}$ \\ ${ }^{1}$ Department of Informatics, Faculty of Socio-pedagogical sciences and foreign philology, Municipal Establishment \\ "Kharkiv Humanitarian-Pedagogical Academy" of Kharkiv Regional Council, Kharkiv, Ukraine \\ ${ }^{2}$ Department of Pedagogy, Psychology, Primary Education and Educational Management, Faculty of Psychological \\ and Pedagogical, Municipal Establishment "Kharkiv Humanitarian-Pedagogical Academy" of Kharkiv Regional \\ Council, Kharkiv, Ukraine \\ ${ }^{3}$ Department of History and Social and Economic Disciplines, Faculty of Preschool and special education and \\ history, Municipal Establishment "Kharkiv Humanitarian-Pedagogical Academy" of Kharkiv Regional Council, \\ Kharkiv, Ukraine \\ ${ }^{4}$ Municipal Establishment "Kharkiv Humanitarian-Pedagogical Academy” of Kharkiv Regional Council, Kharkiv, \\ Ukraine \\ Correspondence: Anna I. Klieba, Municipal Establishment "Kharkiv Humanitarian-Pedagogical Academy" of \\ Kharkiv Regional Council, 7 Rustaveli lane, Kharkiv, 61000, Ukraine. \\ Received: June 10, 2020 \\ Accepted: August 3, 2020 \\ Online Published: August 4, 2020 \\ doi:10.5430/ijhe.v9n7p73 \\ URL: https://doi.org/10.5430/ijhe.v9n7p73
}

\begin{abstract}
The construction of an individual educational trajectory changes due to a change in approaches to the personal and professional potential of the future teacher. Provided that the acquisition of professional skills by a teacher has not required constant training throughout life, then the modern environment requires a systematic updating of skills and advanced training. In fact, approaches to training and the role of the teacher in the educational environment are changing. Based on an integrative literature review, the trends of individual educational tools for the development of the personal and professional potential of a future teacher within EU have been investigated. The academic paper has revealed significant differences regarding the disclosure of personal and professional potential of future teachers within EU. Differences include: teachers' training, the establishment of additional requirements for teachers in addition to curricula, regulating teachers' mobility, professional and personal support, continuing professional development. The article has stated that induction and mentoring for new teachers is widespread within EU and legally established in most European countries. The investigation attests to the fact that induction may play a key role in supporting teachers' professional development. Induction programs combine elements of mentoring, training, peer review, and scheduled meetings with school principals and colleagues to provide personal, social, and professional support. Induction activity is connected with increased self-efficacy and job satisfaction. Mentoring programs are designed taking into consideration the school context. Pupils' knowledge, classroom pedagogy, assessment of pupils and harmonization of curriculum standards differ significantly between primary and secondary schools. Supporting measures to promote teachers' participation have been developed in almost all EU countries.
\end{abstract}

Keywords: professional competence, EU educational programs (curricula), mentoring, mentoring programs, personal potential of teachers, professional potential of teachers, development of teacher's potential, continuing professional development (CPD)

\section{Introduction}

The construction of an individual educational trajectory changes due to an adjustment of approaches to the personal and professional potential of the future teacher. Provided that the acquisition of professional skills by a teacher did not require constant training throughout life, then the modern environment requires a systematic updating of skills and advanced training. In fact, approaches to training and the role of the teacher in the educational environment are changing. Provided that the only possible option for implementing the personal and professional potential of a future teacher was the transition to a higher level position, currently, the approach, providing horizontal career growth, is implemented (Glazerman et al., 2010). Such approach can provide a higher level of attractiveness of the teacher's 
profession. For instance, governments in EU countries offer teachers the opportunity for "career and professional growth" by using the tools of careful professional guidance (Snoek, Dengerink, \& Wit, 2019). Thus, a dynamic approach to the disclosure of personal and professional potential of the future teacher is implemented.

Teacher competence frame works are an important policy measure for the development of the quality of teachers in EU and beyond. European Commission acknowledges the fact that the framework of professional competence is a controversial measure to improve professional quality. This is caused by the diversity of the teacher's professional development policy (recruitment, education, training, advanced training and teachers' assessment) (Caena, 2011; European Commission, 2018b). The Organization for Economic Co-operation and Development (OECD) emphasizes the need to create a profile of teachers' competences in order to reconcile the professional development and effectiveness of teachers, which will meet the needs of the educational environment (Snoek et al., 2019). Teachers' competences are actively discussed in the international community in order to improve the quality of teachers in the labor market (Snoek et al., 2019). There are few examples of the use of teacher competence frameworks within the EU in order to reveal the personal and professional potential of a future teacher, namely: education, selection, promotion and career growth (European Commission, 2018a).

The construction of an individual educational trajectory takes place at different levels: the definition of the criteria for recruitment and selection of teachers at the national level, the formation of curricula for teachers' training; assessment of the professional level of the teacher and the need for professional development (European Commission, 2013); definition of competences at the central level or at the level of the teacher's primary education programs; implementation of professional standards (Caena, 2011).

Taking into consideration different approaches and diversity of policies for construction of an individual educational trajectory in order to reveal the personal and professional potential of the future teacher, the need arises to study the policy features of teachers' personal and professional development in different EU countries.

The purpose of the investigation is to study and generalize individual educational tools for the development of personal and professional potential of future teachers within EU.

Determining the purpose requires the study of the following research issues:

1. Modern individual educational trajectories of EU countries.

2. Goals and objectives of the development of personal and professional potential of the future teacher within EU.

3. Approaches and tools of individual educational trajectories of EU countries in order to ensure the development of personal and professional potential of future teachers.

\section{Literature View}

Teachers' quality and teachers' professional development have become central concerns in national education policies (Snoek et al., 2019) (Figure 1). In a recent Dutch study on the reasons why secondary school students choose or reject a teacher career, more than half mentioned the lack of opportunities for career growth (Bahlmann, Eustatia, \& Pillen Warmerdam, 2018). Teachers who are engaged in post initial Master's programmes sometimes complain that they do not have the opportunity to make use of their newly developed research and design skills, their ability to relate practice to educational theories and their leadership to improve teaching and learning practices at their schools, as their role and responsibilities are limited to their classes (Snoek et al., 2018). Hence, the profession becomes less attractive for highly motivated and potentially highly-skilled teachers who then leave the profession. 


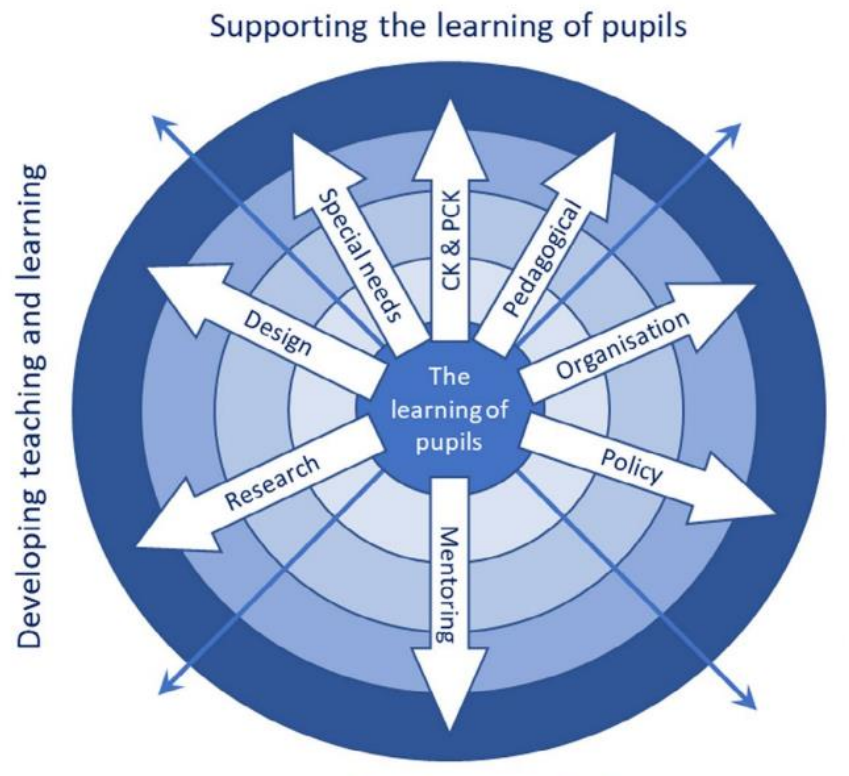

Supporting the learning of colleagues

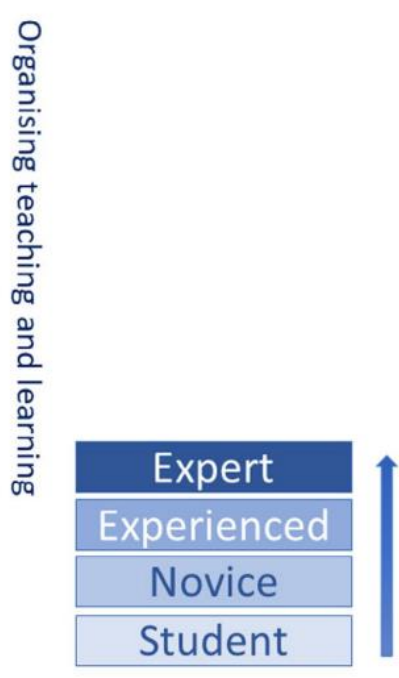

Figure 1. Opportunities for teachers' development and teachers' careers

Source: Snoek et al. (2019)

The scientists Simons and Ruijters (2014) consider that the teacher should now be "the professional, who learns" according to certain standards. Achieving the ultimate goals of national standards in development provides pupils with professional skills and knowledge, increasing the authority of the teacher, independence, forming additional internal motives for self-development of teachers.

The following trends can be observed in the educational environment and in the process of formation of an individual educational trajectory to the disclosure of personal and professional potential of the future teacher, namely:

1) Outspread of systematic teacher's training, professional development, lifelong learning.

2) The use of guidance, mentoring in order to develop personal and professional potential of the future teacher. It is this component of development that provides the construction of an individual educational trajectory for the development of a professional teacher. Mentoring is an important component of continuous professional development and training in the practical experience of implementing European policy of teachers' development (The Educators, n. d.). Mentoring is especially important for young teachers with little practical experience, as it ensures the unity of theoretical training and its use in practice (Helms-Lorenz, Slof \& van de Grift, 2013). At the same time, the investigations note insufficient theoretical training and knowledge base of young teachers (Gjedia \& Gardinier, 2018).

3) Emphasis on the development of digital skills and competences (Wang, 2020).

4) Emphasis on efficiency and learning outcomes (Doğançay-Aktuna \& Hardman, 2018).

5) Intensification of the implementation and updating of standards of the personal and professional potential of the future teacher, in particular, on the basis of standards defining professional competences and procedures, methods and ways of obtaining them. For instance, the Netherlands has introduced a new system of professional competences based on a dynamic approach to the development of future teachers (Snoek et al., 2019).

6) Implementing a policy of vertical and horizontal career growth of teachers, which will increase the attractiveness of the profession.

EU countries have their own systems of teachers' competences in order to identify and assess their effectiveness. In EU countries, a model quality training is usually created, which is crucial for the formation of a list of the teacher's competences. 
We define professional development "as the process of change in a teacher's knowledge base, mental models, personal beliefs, and/or perceptions concerning teaching and learning" (Richardson \& Placier, 2001). It recognizes that professional growth is based on both experience and training.

Sprinthall, Reiman and Thies-Sprinthall (1996) define various interpretations in different models that explain professional development: "craft, expert, and interactive". The craft model based on the point of view that teachers developing in the experience process. Knowledge and skills develop during classroom experience and the study process. However, it is unclear how teachers' arrive at new interpretations. Why teachers reproduce the experience countless times without learning. In the expert model, professional development of teachers is passive; the teachers are trained and taught by experts in education. The interactive interpretation of teachers professional development means professional growth in terms of growing craftsmanship and increasing expertise.

\section{Review Methodology}

\subsection{Design}

An integrative review of literature provides limitations, critiques, and synthesizes of the investigations in an integrated way. Thus, a new viewpoint on the issues of personal and professional development of the future teacher is formed. A review of the literature will provide a better understanding of the educational trajectories of EU countries regarding the development of teachers. Concepts of new educational trajectories are formed on the basis of studying the literature as a consequence of the integrative approach. The methodology of this integrative review included five stages, namely (Cooper, 2001): problem formulation, data collection of relevant empirical research, research evaluation, data analysis, interpretation and presentation of results.

\subsection{Search Methods}

The literature search began with an initial literature study on the teacher's professional development by using the EBSCOhost, A + Education, Proquest Psychology Journals, and Google Scholar, Sage online, Wilson, and Sociological Abstracts databases. Search terms have included a combination of such basic terms, as: guidance, mentoring, educational programs (curricula) for teachers' development or teachers' induction, primary school; or primary school with the following terms: effectiveness, teachers' retention, pupils' performance, teaching (training) methods (Table 1).

Table 1. Search terms

\begin{tabular}{ll}
\hline Location & Search terms with Boolean operators \\
\hline In abstract & EU educational programs(curricula), mentoring, mentoring programs \\
In abstract & Personal potential of a teacher \\
In abstract & Professional potential of a teacher \\
In abstract & Development of a teacher's potential \\
In abstract & Professional and personal support of the teacher, teaching (training) methods
\end{tabular}

Doctoral dissertations have been excluded in the search of the investigations. Interest in the personal and professional development of teachers has gained significant momentum over the past 20 years, and, therefore, the study of major trends includes research articles for the period from 2000 to 2020. As a result, 203 articles have been found by keywords, of which 10 papers have been selected for analysis (Table 2).

Table 2. Screening of journal articles

\begin{tabular}{|c|c|c|c|c|c|}
\hline \multicolumn{2}{|c|}{ Database/source } & \multirow{2}{*}{$\begin{array}{l}\text { Records screened } \\
39\end{array}$} & \multirow{2}{*}{$\begin{array}{l}\text { Abstracts read } \\
8\end{array}$} & \multirow{2}{*}{$\begin{array}{l}\text { Articles read } \\
0\end{array}$} & \multirow{2}{*}{$\begin{array}{l}\text { Included studies } \\
0\end{array}$} \\
\hline $\begin{array}{l}\text { At } \\
\text { (Informit) }\end{array}$ & Education & & & & \\
\hline EBSCOhost & & 77 & 32 & 9 & 7 \\
\hline $\begin{array}{l}\text { Proquest } \\
\text { Journals }\end{array}$ & Psychology & 7 & 7 & 1 & 1 \\
\hline References & & 6 & 6 & 1 & 0 \\
\hline
\end{tabular}




\begin{tabular}{lllll}
\hline SAGE Premier & 21 & 12 & 2 & 0 \\
Google Scholar & 50 & 20 & 8 & 2 \\
$\begin{array}{l}\text { Sociological Abstracts } \\
\text { via Proquest }\end{array}$ & 3 & 3 & 3 & 0 \\
Total & 203 & 88 & 24 & 10
\end{tabular}

The number of studies has been reduced through the revision of research articles and the inclusion of only empirical studies that have included investigations of the basic directions of movement in ensuring the personal and professional development of teachers.

\section{Results}

\subsection{Modern Individual Educational Trajectories of Movement of EU Countries}

EU recommends its member states to move towards the development of "empowerment and responsibility of teaching staff, rather than their control and disempowerment" (European Commission, 2013). The approach focused on dynamic professional development determines the individual educational trajectories of movement of EU countries. This approach is opposed to a technical or bureaucratic approach; it requires the involvement of interested parties in order to develop teachers' competence profiles (European Commission, 2013).

The European Qualification Framework / National Qualification Framework (EQF / NQF) has been adopted within EU, providing lifelong learning on the basis of 8 reference levels that determine the outcome of the teacher's training at each level. These standards have been adopted to equalize the qualifications of teachers within EU. "The EQF is a common European reference system, which will link different countries' national qualifications systems and frameworks together" (The Educators, n. d.).

Adoption of NQF within EU is caused by the need to integrate and coordinate qualifications obtained in the native subsystems of education and training in a single structure, assessment and review of competences of formal and non-formal education, improving transparency and comparability of qualifications, assessment of double certification (European Commission, 2018a; European Commission: Eurydice, 2018). The aging of teachers is an additional problem that has necessitated the adoption of the NQF within EU.

The shortage of teachers and the aging of teachers are the most common problems in terms of supply and demand of teachers in Europe. Most countries face a numerous challenges; many of challenges are related to the general problem of the profession's attractiveness. Lack of teachers, specializing in some subjects, is the most common problem. This problem exists in most of education systems in EU. However, the incentives using in order to involve students in the profession or in specific subjects, is a rare practice in particular. The lack of a proposal is in several countries because of such reasons as uneven distribution of education items and geographical areas of regions of the countries (Germany, Spain, Greece, Italy, Liechtenstein, Lithuania, and Montenegro) (European Commission: Eurydice, 2018).

Almost half of the countries face the problem of teachers' aging. Some countries also face problems concerning retaining young teachers in the profession. The experience of half of countries indicates a shortage of students that enrolle in primary teacher's education programs (ITE), and four EU countries note a high level of dropout from ITE among their basic problems, namely: Netherlands, Denmark, Norway and Sweden.

About a third of education systems in EU offer alternatives in the sphere of the teacher's qualifications alongside basic curricula. Alternative pathways are usually developed as part of short professional and / or employment-based training programs. Many countries have no alternatives in the process of development of the teaching profession, despite the shortage of teachers.

The educational systems of EU countries establish the requirements that must be met by graduates of curricula. The teachers are qualified after graduating from ITE in 20 European education systems. The teachers in the sphere of education should also meet requirements in 23 other systems of education. Six systems of education require the students to pass a competitive exam, and in the other $17 \mathrm{EU}$ countries candidates for the position of teacher should prove their professional competence. This last requirement is confirmed by examination or assessment at the entrance program end or in the accreditation, registration, and certification (European Commission: Eurydice, 2018).

Teachers are hired by local authorities or schools. In half of European education systems, local authorities or schools responsible for teachers recruiting. Such a decentralized approach is based on an open recruitment system. This 
means local authorities or schools manage vacancies directly, and teachers apply for vacancies. Higher education institutions are generally responsible for the selection, recruitment and training of qualified teachers in EU education systems, where recruitment is based on competitive examinations or lists of candidates. In EU education systems, teachers have the opportunity to obtain an employment contract for an indefinite period. In 16 of the 28 countries, education systems legislatively regulate contractual relations in the public sector and the teacher's employment status. In the education systems of 16 countries, all teachers work under contracts in accordance with general employment legislation.

Teachers' mobility (that is, moving from position to position across schools) is regulated within EU, but not in every country. In countries with the regulations exist concerning this issue, the rule of law is largely applied by higher authorities, with the exception of Albania and Macedonia, where mobility regulation exist at the local level. In general, teachers move for personal and / or professional reasons. Reorganization of schools in the education system is most common in the EU due to such problems as the need to ensure a balanced distribution of teachers, professional development of teachers, personal problems of teachers.

\subsection{Goals and Objectives of the Development of Personal and Professional Potential of Future Teachers Within EU}

Personal, professional support of teachers is provided in order to ensure the attractiveness of the profession in education systems. Solving personal difficulties, for example, in the case of school reorganization, labor migration (mobility) is an additional factor in keeping a teacher in the profession. Another important factor is the optimization of professional practice, the development of vertical and horizontal career success of teachers. Despite this, the profession of the teacher is not currently popular among young people. Although the individual educational trajectory reveals personal and professional potential, all existing problems in this area are on the agenda in EU.

In case of difficulties for students, support and assistance in the educational process is provided to students in EU. Educational psychologists, pedagogues, speech therapists provide similar support. This means that the practice of pedagogical and psychological support is integrated into the educational process to ensure personal and professional development.

Involving into continuing professional development (CPD) is a common practice. Obligation to CPD is provided within most EU countries by determining the duration (days, credit) of professional development (European Commission: Eurydice, 2018). There is also the practice of establishing the teacher's independent responsibility for professional development. This practice can be effective in the case of financial support, however, it is limited. Otherwise, in countries with fewer opportunities to fund professional development, the practice of personal responsibility can be an additional burden on teachers. As a result, the profession of the teacher will become less attractive. In some countries, teachers have a commitment to provide professional development for themselves. Lack of optimal combination of motivation - the duty of professional development can be a problem in keeping a teacher in the profession.

Countries determine the necessary stage of professional development in order to increase the level of wages (European Commission: Eurydice, 2018). Such position is justified, because career growth must be accompanied by the acquisition of additional competences and personal qualities. In particular, the position of the mentor or the manager requires personnel management skills. In this case, it is not possible to ensure career growth without professional development.

4.3 Approaches and Tools of Individual Educational Trajectories of the EU Countries in order to Ensure the Development of Personal and Professional Potential of Future Teachers

Teachers - beginners need professional support. To this end, the education system includes the practice of mentoring or induction. Induction includes such elements as mentoring, learning, development, support from the school principal. Mentoring, for example, is mandatory in 26 countries; it is recommended in 5 countries (European Commission: Eurydice, 2018). At the same time, there is no mentoring practice for teachers in permanent positions. The authors of the academic paper adhere the opinion that the practice of mentoring should be implemented throughout life. Mentoring provides additional motivation for personal and professional development like lifelong learning. Mentoring is also an element of counteracting emotional burnout and support, sharing experiences.

Only at schools of Estonia and Finland mentoring for any teacher, who needs support, is recommended (European Commission: Eurydice, 2018). In almost all countries where introduction is mandatory, teachers are assessed at the end of the period. Assessment is a complete formal process of testing and certifying practical teaching skills. Ireland uses two models of induction: 1) master classes within the national induction program (20 hours of seminars for teachers); 2) the Droichead system combines induction and internship / training. 100 hours of attendance for a 
primary schools teacher and 300 hours for a high school teacher are necessary to graduate from Droichead. Teachers - beginners can choose any induction program.

In Greece, induction is available to teachers across all country - beginners. Induction is mandatory for teachers beginners holding permanent positions, while it is recommended only for teachers who are temporarily working.

In Spain, the induction phase essence, content, duration vary depend on the relevant autonomous community. In Italy, teachers must complete 180 school service days (120 teaching days) during one year.

In the Netherlands, the social partners determine the basis for the promotion of collective labor agreements. Recommendations for early teacher's support are provided and developed by schools. The induction is mandatory in Austria only for graduates who have initially completed initial training (Allgemeinbildenden höheren Schulen, ISCED 2-3).

Studies have revealed that induction can play a key role in supporting the professional development of teachers (Ashby et al., 2008). Induction is positively related to teaching practice and teaching outcomes (Ingersoll \& Strong, 2011). Typically, induction programs combine elements of mentoring, training, expert reviews, and scheduled meetings with school principals and colleagues in order to provide personal, social, and professional support (European Commission: Eurydice, 2018). The data also attests to the fact that induction activity is connected with increased self-efficacy and job satisfaction. In countries where part of the initial training sessions for practical training is shorter, more intensive induction and mentoring programs can help provide teachers - beginners with the necessary practical experience at the early stage of the career by bridging the gap between theory and practice (Schleicher, 2018). In the TALIS survey, about 39\% of teachers stated that they had participated in some form of induction when recruiting for school.

Mentoring is one of the basic stages of induction programs, and it usually includes personal, social and professional support of teachers. A mentor, as a rule, is a senior teacher who acquaints new teachers with colleagues, as well as with professional life, supports them and provides coaching, pieces of advice, if necessary. The investigations show that mentoring has a positive effect on training skills, for as much as mentors often possess school-specific information that new teachers may lack; consequently, they can also help retain teachers (Rockoff, 2008). Mentoring is a mandatory component of induction programs in all education systems where induction is regulated, except in Ireland, where it is not compulsory (European Commission: Eurydice, 2018). Within the framework of the TALIS 2018 program, 34\% of principals have reported that school mentoring is only available to teachers who are unfamiliar with teaching; while $15 \%$ have reported about the availability of a school mentoring program for all teachers (Schleicher, 2018).

Figure 2 indicates that scientific performance in the subject is the most important element considered by the mentors (67\%) This echoes the perspectives of the teacher-candidate focus group which noted that one of the most valuable aspects of mentoring was that it helped them to link their theoretical training to their teaching practice. Participants felt that this was a positive step in the development of their professional skills and noted that their relationship with the mentors was generally very good. However, this indicates not only the importance placed on the teacher's scientific training, but also the mentors' general dissatisfaction with the state of teacher training in Albania, particularly in the area of subject matter competence. Alongside the concern of mentors regarding new teachers' insufficient knowledge base, many pre-university school directors have informally criticized the methodological preparation of their newer teachers. Thus, the challenge of teacher preparation cannot be addressed through mentoring alone.

The mentoring of new teacher-candidates is an important area of educational research that has attracted international attention. With the increasing demand for evidence-based practice in schools and a policy emphasis on teaching as a primary factor for improving students' learning outcomes, mentoring in the early years of a teacher's career can help teacher-candidates to establish effective teaching practices that will serve them throughout their career. In addition, with the new legal requirement of teacher licensing in $\mathrm{EU}$, the provision of effective mentoring in the first year of teaching takes on added significance for the profession. Mentoring can strengthen the teaching profession across EU. $85 \%$ of mentors and $87 \%$ of non-mentor teachers perceived that the greatest strength of mentoring was the transfer of the professional elements of the work of teachers to the teacher-candidates (Gjedia \& Gardinier, 2018). 


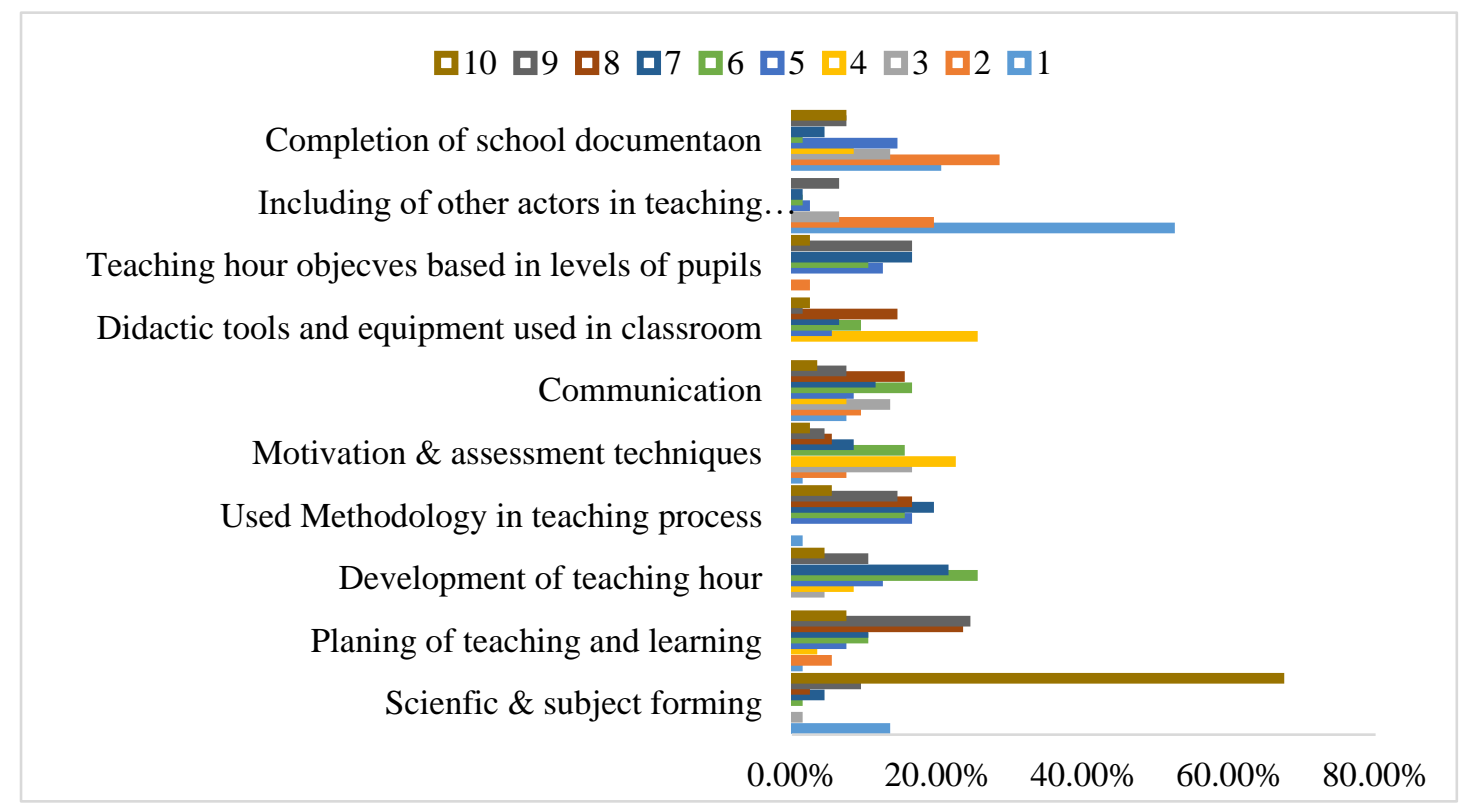

Figure 2. Ranking of the professional elements of the mentor's service, according to importance [Colour figure can be viewed at wileyonlinelibrary.com]

Source: Gjedia and Gardinier (2018)

Mentoring programs are designed taking into consideration the school context. Pupils' knowledge, classroom pedagogy, assessment of pupils and harmonization of curriculum standards differ significantly between primary and secondary schools. For instance, there are visible differences between primary and secondary school teachers' management strategies, training strategies, substantial knowledge, curriculum preparation and assessment, and timing (Spooner-Lane, 2017).

Continuing professional development is an important way for teachers to maintain and improve their training skills, be aware of the latest developments in education and their own subjects, and be aware of pupils' needs in a rapidly changing society. As a result of a comparative analysis of the policy in the field of the teacher's professional development, the OECD (2018), has concluded that the countries with the highest learning outcomes have three common elements: compulsory and long-term period of practice either during obtaining primary education by teachers or during implementation of their training skills (working); offering quality opportunities for continuing professional development; and teachers' assessment mechanisms with a strong focus on teachers' needs.

In $11 \mathrm{EU}$ countries, teachers, involved in primary and general secondary education, are required to participate in professional development (that is, there is a minimum amount of continuous professional development that must be passed) (European Commission: Eurydice, 2018). Teachers must complete a certain minimum amount of training per year in these programs. In $10 \mathrm{EU}$ countries, teachers with higher secondary education are required to participate in professional development in order to maintain employment, and in $6 \mathrm{EU}$ countries this is mandatory step for rising of qualification or for raising salaries. In addition, professional development is mandatory in some regions of two EU countries (French Community of Belgium, the United Kingdom -Scotland and the United Kingdom-Northern Ireland). In other theories of Belgium and the United Kingdom, as well as in other nine EU countries, continuing professional development is considered a professional duty of a teacher(when it is a professional duty, professional development is classified in regulations or applicable policy documents, however, without the minimum number of mandatory hours). In France, primary school teachers are obliged to participate in the professional development. 
Participation in professional development in primary and general secondary education is optional in Denmark, Greece, Ireland, the Netherlands and Sweden.

Supporting measures concerning promotion of teachers' participation in the CPD exist in all European countries. Measures are aimed at removing barriers to professional development and participation in development. These barriers include: teachers' costs, existing conflicts (turnover schedule, for example), family. The cost of courses is covered by the state. In some countries, schools are funded by the state in order to organize activities in the context of professional development. However, the profession of the teacher is not attractive enough. Attendance of events takes place during working hours with certain restrictions. The cost of business trips is covered.

Additional benefits, grants, paid study leave are provided to teachers in some countries. Schools determine the needs for personal and professional development. Education authorities are also involved in this process. However, in general, schools within EU make their own decisions, which also include the development of a professional development plan.

Most education systems have developed a multi-level career structure that provides career development. Career levels are structured according to the level of complexity and responsibility. The unified career structure in some countries is called a "flat career structure" (European Commission: Eurydice, 2018).

The multilevel structure of career development is connected with increase of wages and holding particular positions, except for Estonia and Serbia. At the same time, in these countries, a higher level of qualification determines a greater variety of tasks. On the negative side, additional responsibilities in extracurricular activities are not always part of a multilevel career structure. A variety of positions is actually provided in all EU countries; it provides a high level of attractiveness of the profession. Teachers have the opportunity to be mentors in the induction program. This is regulated by local authorities or at the school level. There is a possibility of obtaining a pedagogical role or the role of a methodologist, which provides support for students, curricula or school life. Teachers have the opportunity to get a leadership position.

"Teacher competence frameworks" are defined and vary within EU countries. The structure of the teacher's competence determines the structure of the competence framework. For example, Albania, Bosnia and Herzegovina are currently developing such a structure. Despite the definition of the competences and areas of activity of the teacher, the detailed elaboration depends on the education system operating in the country. There are cases of developing a list of competences without detailing their essence. However, in general, the approved framework specifies skills, abilities and knowledge. At different stages of a teacher's career there may be different competence frameworks (4 countries). The basic purpose of this practice is to determine the competences for a potential candidate for the position of teacher. In the future, the structure of the competence framework will become more comprehensive, taking into account continuous professional development, mentoring.

The experience of Germany shows that the relevant curricula and lesson plans have been improved for widespread within the country (Mamlok-Naaman \& Eilks, 2012). The study notes that innovative programs have only partially succeeded in acquiring professional knowledge for future teachers (Buchholtz \& Kaiser, 2013).

In Germany, after successful completion of training (Vorbereitungsdienst), teachers - beginners can apply for permanent employment in public schools (European Commission: Eurydice, 2018). From the land plot the application is sent to the controlling body of the school or the Ministry of Education and Culture. Recruitment is a centralized decision based on available vacancies in accordance with the criteria of suitability, achievement and qualification. Positions in the provinces may qualify according to the profile of the school, selecting teachers. This sometimes involves sending applications directly to the school. Successful potential teachers are generally hired by civil servants on probation. 


\section{Discussion}

Studies have shown that mentoring and induction programmes have been an important aspect of teacher education in many countries worldwide, particularly since the 1980s (Gjedia \& Gardinier, 2018). Mentoring has been found to increase teacher retention (Doğançay-Aktuna \& Hardman, 2018), improve new teacher job satisfaction and self-efficacy (Ingersoll \& Strong, 2011), enhance teachers' pedagogical content knowledge (Spooner-Lane, 2017), reduce new teachers' feelings of isolation (Mamlok-Naaman \& Eilks, 2012) and promote teachers' ongoing professional development and lifelong learning (Snoek et al., 2018).

The research evidence identifies two contrasting approaches to [teachers'] training and development. A constructivist approach enables teachers to take responsibility for developing their practices within the framework for teacher education. A transmission approach develops these practices on behalf of teachers and offers them to teachers for them to use. There is some research evidence to suggest that, whilst the transmission approach can result in changes in practices that are procedurally consistent with the training and development, the constructivist approach can result in changes that have a stronger conceptual basis. Furthermore, the constructivist approach appears more consistent with the emphasis on a range of learning contexts emphasized by key competences and therefore more likely to help teachers promote them in and beyond the classroom.

\section{Conclusion}

The study conducted indicates the differences in the construction of individual educational paths to the disclosure of the personal and professional development of teachers. Within EU, there are differences in the application of incentives in order to involve students in the teaching profession, ways to improve teachers' qualification, setting additional requirements for teachers, in addition to the initial programs. EU countries also differ in hiring procedures, although the generally widespread decentralized approach to recruiting teachers is applied. This decentralized approach is usually based on an open recruitment system and means that schools or local authorities manage vacancies directly, and teachers apply for specific vacancies. It is common practice within EU to regulate teachers' mobility. However, in countries where there are regulations on this issue, the rule of law is largely applied by higher authorities.

Professional and personal support is provided to teachers in most EU education systems. Teachers are able to receive professional help to solve different types of difficulties: in improving their relationships with pupils, parents or other colleagues; to improve their professional practice; to address personal issues. In most countries, teachers must be involved in continuing professional development (CPD). In almost half of the education systems, CPD is mandatory for teachers, there is a minimum number of hours, days or credits that teachers must pass. Induction and mentoring for new teachers is widespread within EU and legally established in most European countries.

\section{References}

Ashby, P., Hobson, A., Tracey, L., Malderez, A., Tomlinson, P., Roper, T. Chambers, G., \& Healy, J. (2008). Beginner Teachers' Experiences of Initial Teacher Preparation, Induction and Early Professional Development: A review of literature. Retrieved from https://dera.ioe.ac.uk/8564/1/dcsf-rw076.pdf

Bahlmann, M., Eustatia, B., \& PillenWarmerdam, D. (2018). Optimale inrichting van lerarenopleidingen. Resultaten van een vignette en motievenonderzoek onder havisten, vwo'ers en mbo4 studenten [Optimal design of teacher education. Results of a survey among students in upper secondary education]. Leiden, Netherlands: Qompas.

Buchholtz, N., \& Kaiser, G. (2013). Improving mathematics teacher education in Germany: empirical results from a longitudinal evaluation of innovative programs. International Journal of Science and Mathematics Education, 11, 949-977. https://doi.org/10.1007/s10763-013-9427-7

Caena, F. (2011). Literature review. Teachers' core competences: Requirements and development. Retrieved from https://ec.europa.eu/assets/eac/education/experts-groups/2011-2013/teacher/teacher-competences_en.pdf

Cooper, H. M. (2001). Synthesizing research: A guide for literature review (3rd ed.). Newbury Park, CA: Sage.

Doğançay-Aktuna, S. \& Hardman, J. (2018). Teacher Qualifications, Professionalism, Competencies, and Benchmarks. In The TESOL Encyclopedia of English Language Teaching. New York, NY: John Wiley \& Sons, Inc. https://doi.org/10.1002/9781118784235.eelt0034

European Commission. (2013). Supporting teacher competence development for better learning outcomes. Retrieved from https://ec.europa.eu/assets/eac/education/experts-groups/2011-2013/teacher/teachercomp_en.pdf 
European Commission. (2018a). Boosting teacher quality - Pathways to effective policies. Luxembourg: Publications Office of the European Union.

European Commission. (2018b). National Qualifications Framework. Retrieved from https://eacea.ec.europa.eu/national-policies/eurydice/content/national-qualifications-framework-60_en

European Commission: Eurydice. (2018). Teaching Careers in Europe: Access, Progression and Support. Eurydice Report. Luxembourg: Publications Office of the European Union.

Gjedia, R., \& Gardinier, M. P. (2018). Mentoring and teachers' professional development in Albania. European Journal of Education, 53(1), 102-117. https://doi.org/10.1111/ejed.12258

Glazerman, S., Isenberg, E., Dolfin, S., Bleeker, M., Johnson, A., Grider, M., \& Jacobus, M. (2010). Impacts of comprehensive teacher induction: Final results from a randomized controlled study (NCEE 2010-4028). Washington, DC: National Center for Education Evaluation and Regional Assistance, Institute of Education Sciences, U.S. Department of Education.

Helms-Lorenz, M., Slof, B., \& van de Grift, W. (2013). First year effects of induction arrangements on beginning teachers' psychological processes. The European Journal of Psychology of Education, (28)4, 1265-1287.

Ingersoll, R., \& Strong, M. (2011). The impact of induction and mentoring programs for beginning teachers: A critical review of the research. The Review of Educational Research, 81(2), 201-233. https://doi.org/10.3102/0034654311403323

Mamlok-Naaman, R., \& Eilks, I. (2012). Different types of action research to promote chemistry teachers professional development - a joined theoretical reflection on two cases from Israel and Germany. International Journal of Science and Mathematics Education, 10, 581-610. https://doi.org/10.1007/s10763-011-9306-z

OECD. (2018). Effective Teacher Policies: Insights from PISA. Paris, France: OECD Publishing. http://dx.doi.org/10.1787/9789264301603-en

Richardson, V., \& Placier, P. (2001). Teacher change. In V. Richardson (Ed.), Handbook of research on teaching (pp. 905-947). Washington, DC: American Educational Research Association.

Rockoff, J. (2008). Does mentoring reduce turnover and improve skills of new employees? Evidence from teachers in New York City. NBER Working Paper, No. w13868.

Schleicher, A. (2018). Teaching and Learning International Survey (TALIS): Conceptual Framework. Retrieved from

http://www.oecd.org/officialdocuments/publicdisplaydocumentpdf/?cote=EDU/WKP(2018)23\&docLanguage= En

Simons, P. R.-J., \& Ruijters, M. C. P. (2014). The real professional is a learning professional. In S. Billett, C. Harteis, \& H. Gruber (Eds.), International handbook of research in professional and practice based learning (pp. 955-985). Dordrecht, Germany: Springer. https://doi.org/10.1007/978-94-017-8902-8_35

Snoek, M., Dengerink, J., \& Wit, B. (2019). Reframing the teacher profession as a dynamic multifaceted profession: A wider perspective on teacher quality and teacher competence frameworks. European Journal of Education, 54, 413-425. https://doi.org/10.1111/ejed.12350

Snoek, M., Knezic, D., Van den Berg, E., Emmelot, Y., Heyma, A., \& Sligte, H. (2018). Impact of in-service Master of Education programmes on teachers and their working environment. European Journal of Teacher Education, 41, 620-637. https://doi.org/10.1080/02619768.2018.1529755

Spooner-Lane, R. (2017). Mentoring beginning teachers in primary schools: research review. Professional Development in Education, 43, 253-273. https://doi.org/10.1080/19415257.2016.1148624

Sprinthall, N. A., Reiman, A. J. \& Thies-Sprinthall, L. (1996). Teacher professional development. In J. Sikula, T. J. Buttery \& E. Guyton (Eds.), Handbook of research on teacher education. New York, NY: Macmillan.

The Educators. (n.d.) EQF Levels. Retrieved from http://www.theeducators.com/home/certificate/system-guidelines/

Wang, J. (2020). Teacher mentoring in service of beginning teachers' learning to teach. In S. J. Zepeda \& J. A. Ponticell (Eds.), The Wiley Handbook of Educational Supervision (pp. 281-306). New York, NY: John Wiley \& Sons, Inc. https://doi.org/10.1002/9781119128304.fmatter 